\title{
Preliminary Characterization of Xylose Reductase Partially Purified by Reversed Micelles from Candida tropicalis IEC5-ITV, an Indigenous Xylitol-Producing Strain
}

\author{
Yolanda Cocotle-Ronzon ${ }^{1}$, Marisol Zendejas-Zaldo ${ }^{1}$, Micloth López del Castillo-Lozano², \\ MaGuadalupe Aguilar-Uscanga ${ }^{3^{*}}$ \\ ${ }^{1}$ Facultad de Química Farmacéutica Biológica, Universidad Veracruzana, Veracruz, México \\ ${ }^{2}$ Instituto de Ciencias Básicas, Universidad Veracruzana, Veracruz, México \\ ${ }^{3}$ Instituto Tecnológico de Veracruz, Unidad de Investigación y Desarrollo de Alimentos, Veracruz, México \\ Email: ${ }^{*}$ maguilaruscanga@yahoo.com.mx,ycocotle@uv.mx
}

Received September 10, 2011; revised October 24, 2011; accepted November 6, 2011

\begin{abstract}
Xylose reductase (EC 1.1.1.21) of Candida tropicalis IEC5-ITV, an indigenous xylitol-producing strain, was partially purified by reversed micelles and characterized, an 8.1 fold purification factor being obtained. The XR present in the crude extract exhibited its highest specific activity at $\mathrm{pH} 6.0$ and $40^{\circ} \mathrm{C}$, while in that obtained by reverse micelles, this occurs at $\mathrm{pH} 6.0$ and $30^{\circ} \mathrm{C}$. XR before and after extraction is stable within a range of $30^{\circ} \mathrm{C}$ to $40^{\circ} \mathrm{C}, \mathrm{pH} 7$ after one hour of incubation under these conditions. After two months' storage at $-18^{\circ} \mathrm{C}$, the enzyme obtained by reverse micelles lost $76.60 \%$ specific activity. The estimated molecular weight by PAGE-SDS was $32.42 \mathrm{kD}$. $\mathrm{K}_{\mathrm{M}}$ for xylose was higher for the XR extracted by reverse micelles $(0.026 \mathrm{M})$ than that obtained for the enzyme before extraction $(0.0059 \mathrm{M})$, while $\mathrm{K}_{\mathrm{M}}$ for cofactor NADPH was lower after than before extraction $(1.85 \mathrm{mM}$ to $12.0 \mathrm{mM}$ respectively). There was no activity with NADH as a cofactor. Variations in $\mathrm{pH}$ and temperature optima, as well as kinetic parameters before and after partial XR purification by reverse micelles are probably due to an alteration in enzyme molecule structure caused by the solvents used during extraction.
\end{abstract}

Keywords: Xylose Reductase; Xylitol; Reversed Micelles; Candida tropicalis

\section{Introduction}

Extraction by reverse micelles is a useful versatile tool for separating biomolecules such as enzymes. This method involves the use of ternary mixtures composed of water-surfactant-solvent which in a first step (forward extraction), through agitation, leads to the aggregation of surfactant molecules that form a hydrophilic core (reverse micelles) where the enzyme to be purified can be integrated. In a second step (backward extraction), through its transfer to a new aqueous phase the enzyme of the reverse micelles is released, so that a quantitative recovery of purified protein is observed [1]. The extraction of enzymes by reverse micelles has been demonstrated for a number of enzymes in various reverse micelles systems: porcine pepsin and bovine chymosin [2], alcohol dehydrogenase [3], xylanase [4], $\beta$ xylosidase [5], glucose oxidase [6], nattokinase [7], xylitol dehydrogenase [8,9] and xylose reductase [9-11].

"Corresponding author.
Yeast aldose reductases belong to the aldo-keto reductase superfamily of enzymes whose members are responsible for a wide variety of biological functions in organisms that contain them. Thus, xylose reductase (EC 1.1.1.21) catalyzes the reversible reduction of D-xylose to xylitol in the cytoplasm of the yeast that consumes or ferments pentoses. The xylitol thus produced can be oxidized to xylulose or released into the environment depending on organism culture conditions [12].

Xylitol is a valuable sweetener which has applications in the food and pharmaceutical industries. Its biotechnological production from yeast and agro-industrial waste hydrolysates, such as sugar cane bagasse, rich in D-xylose, are a cheaper alternative production of this sweetener, which is currently synthesized by chemical methods [13]. Xylose reductase is one of the key enzymes for xylitol production, so understanding the mechanisms that regulate its activity could aid in establishing optimal conditions for xylitol production. This research evaluates the 
effectiveness of reversed micelles in the extraction and purification of xylose reductase from the xylitol producing indigenous yeast Candida tropicalis IEC5-ITV grown in hydrolyzed sugar cane bagasse-like synthetic medium, in addition to determining some biochemical characteristics of this enzyme.

\section{Materials and Methods}

\subsection{Microorganism and Inoculum Preparation}

Candida tropicalis IEC5-ITV was isolated in the Bioengineering Laboratory of the Veracruz Institute of Technology. The yeast was maintained at $4^{\circ} \mathrm{C}$ on agar $(25.0$ $\mathrm{g} / \mathrm{L})$, yeast extract $(10.0 \mathrm{~g} / \mathrm{L})$ and xylose $(20.0 \mathrm{~g} / \mathrm{L})$. The inoculum was grown by transferring three loops of the organism to a $500 \mathrm{~mL}$ Erlenmeyer flask with $250 \mathrm{~mL}$ synthetic medium (xylose $20.0 \mathrm{~g} / \mathrm{L}, \mathrm{KH}_{2} \mathrm{PO}_{4} 5.0 \mathrm{~g} / \mathrm{L}$, $\left(\mathrm{NH}_{4}\right)_{2} \mathrm{SO}_{4} 2.0 \mathrm{~g} / \mathrm{L}, \mathrm{Mg}\left(\mathrm{SO}_{4}\right) \quad 7 \mathrm{H}_{2} \mathrm{O} 0.4 \mathrm{~g} / \mathrm{L}$ and yeast extract $1.0 \mathrm{~g} / \mathrm{L}), \mathrm{pH} 5.5$ and incubated with agitation at $30^{\circ} \mathrm{C}, 24 \mathrm{~h}, 250 \mathrm{rpm}[14]$.

\subsection{Fermentation Conditions and Crude Extract Obtention}

A $500 \mathrm{~mL}$ Erlenmeyer flask containing $300 \mathrm{~mL}$ hydrolyzed sugar cane bagasse-like synthetic medium xylose $(30 \mathrm{~g} / \mathrm{L})$, glucose $(2.68 \mathrm{~g} / \mathrm{L})$, arabinose $(3.4 \mathrm{~g} / \mathrm{L})$, acetic acid $(5.0 \mathrm{~g} / \mathrm{L})$ and furfural $(<0.05 \mathrm{~g} / \mathrm{L})$, was inoculated with $6 \times 10^{6}$ viable cells $/ \mathrm{mL}$. This medium also enriched with urea $(3.0 \mathrm{~g} / \mathrm{L}), \mathrm{KH}_{2} \mathrm{PO}_{4}(5.0 \mathrm{~g} / \mathrm{L})$ and yeast extract $(1.0 \mathrm{~g} / \mathrm{L}), \mathrm{pH}$ adjusted to 5.5 was then incubated with agitation at $30^{\circ} \mathrm{C}, 24 \mathrm{~h}, 250 \mathrm{rpm}$ [14]. The cells were harvested by centrifugation at $2700 \mathrm{~g}$ (Hermle Z $300 \mathrm{~K}^{\mathbb{R}}$ ) for $20 \mathrm{~min}$ at $4^{\circ} \mathrm{C}$. The biomass was washed with deionized water, weighed and resuspended in $0.1 \mathrm{M}$ phos-

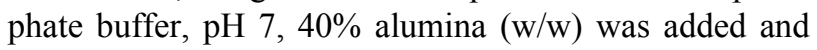
stored at $-70^{\circ} \mathrm{C}$, then thawed and macerated with mortar and pestle until at least $85 \%$ broken cells were observed under the microscope in a Thoma chamber. The cell homogenate was centrifuged at $2700 \mathrm{~g}$ for 20 minutes at $4^{\circ} \mathrm{C}$. The supernatant (crude extract) was used for subsequent enzyme assays. The protein concentration was determined by the Bradford method, using bovine serum albumin as a standard [15].

\subsection{Extraction and Purification of Xylose Reductase (XR) in Reverse Micelles}

Extraction and purification was performed according to Cortez et al. [11], except that electrical conductivity was not adjusted. Three $\mathrm{mL}$ crude extract (CE) was mixed with an equal volume of micellar microemulsion, composed of cetyl trimethyl ammonium bromide (CTAB)/ isooctane $0.15 \mathrm{M}$, hexanol $5 \%, 22 \%$ butanol, $\mathrm{pH} 7$ to $5^{\circ} \mathrm{C}$. This mixture was mechanically stirred (vortex mixer) for
$1 \mathrm{~min}$ to obtain equilibrium then centrifuged at $1735 \mathrm{~g}$ for $10 \mathrm{~min}$ at $5^{\circ} \mathrm{C}$. Two phases were obtained (micellar phase I and aqueous phase I). To transfer the enzyme contained in the micellar phase I to a fresh aqueous phase, $2 \mathrm{~mL}$ micellar solution were mixed with $2 \mathrm{~mL} 1.0 \mathrm{M}$ acetate buffer, $\mathrm{pH} 5.5,1.0 \mathrm{M} \mathrm{NaCl}$, stirred with a vortex mixer for $1 \mathrm{~min}$, then centrifuged at $1735 \mathrm{~g}$ for 10 $\min$ at $5^{\circ} \mathrm{C}$ to separate the aqueous phase II (APII) from the micellar solution. Two clear phases were obtained, with a small amount of white material collected at the interface. Determinations were made for protein concentration and enzyme activity for both aqueous phases I, II and $\mathrm{CE}$.

\subsection{Enzyme Activity}

Reaction medium constituents for the measurement of xylose reductase (XR) activity were: deionized water 100 $\mu \mathrm{L}, 0.1 \mathrm{M}$ phosphate buffer, $\mathrm{pH} 7.0,600 \mu \mathrm{L}, 0.1 \mathrm{M} \beta-$ mercaptoethanol, $100 \mu \mathrm{L}, 50 \mu \mathrm{L}$ enzyme extract, $50 \mu \mathrm{L}$ 3.0 M NADPH. The reaction was initiated with the addition of $100 \mu \mathrm{L} 0.5 \mathrm{M}$ D-xylose, and NADPH consumption was followed by the change in absorbance for $1 \mathrm{mi}-$ nute at $340 \mathrm{~nm}$ (Genesys 10 UV-VIS, Thermo Scientific) [16]. Activity determination was performed in duplicate on at least 2 crude extracts obtained at different times. One unit (U) XR activity is defined as the amount of enzyme required to catalyze the formation of $1 \mu \mathrm{mol} \mathrm{NADP}{ }^{+}$per min using an extinction coefficient of $6.22 \times 10^{-3}$ $\mathrm{M}^{-1} \cdot \mathrm{cm}^{-1}$. Each experiment was performed in triplicate, and the results were expressed as average values.

\subsection{Effect of $\mathrm{pH}$ and Temperature on Enzyme Activity and Stability}

$\mathrm{XR}$ activity was evaluated at room temperature by varying the $\mathrm{pH}$ of the enzyme assay using appropriate $0.1 \mathrm{M}$ buffer from 4.5 to 8.5 . Stability was determined by incubating the enzyme solution $1 \mathrm{~h}$ at room temperature to the desired $\mathrm{pH}$ before the standard test to determine XR activity. The temperature of the enzymatic assay varied from $30^{\circ} \mathrm{C}$ to $60^{\circ} \mathrm{C}$. Enzyme stability was evaluated by incubating it for $1 \mathrm{~h}$ at the desired temperature before activity determination [17].

\subsection{Determination of $K_{M}$ and $V_{M a x}$}

Apparent XR kinetic constants were determined by the Lineweaver-Burke method, changing substrate and cofactor concentrations at intervals from $0.0 \mathrm{M}$ to $0.25 \mathrm{M}$ for xylose, and $0.03 \mathrm{mM}$ to $0.18 \mathrm{mM}$ for NADPH according to the standard assay [17].

\subsection{Enzyme Stability during Storage}

$\mathrm{CE}$ and purified enzyme (PAII) samples were stored at 
$-18^{\circ} \mathrm{C}$. After 2 months, enzyme activity was determined in both samples at room temperature.

\subsection{Molecular Weight Determination of Xylose Reductase}

The protein present in the crude extract and the aqueous phase II were concentrated by ultrafiltration at $4^{\circ} \mathrm{C}$ using a stirred Amicon cell 8200 equipped with a PM 10 filter (cut off 10,000). Sodium dodecyl sulfate-polyacrylamide gel elelectrophoresis (SDS-PAGE) [15] was performed using a Bio-Rad Mini Protein electrophoresis unit, using a molecular weight marker (Bio-rad ${ }^{\mathbb{B}}$ Precision Plus Dual Color Standards Protein ${ }^{\mathrm{TM}}$ ). A $0.025 \mathrm{~mL}$ amount of a 2 $\mathrm{mg} / \mathrm{mL}$ protein solution was loaded per well. The gel was stained with Coomassie Brilliant Blue R 25.

\section{Results and Discussion}

\subsection{Extraction and Purification of Xylose Reductase by Reverse Micelles}

The extraction process by reverse micelles is mainly determined by electrostatic interactions between a charged protein and the micellar wall. Protein transfer during the forward extraction only takes place when aqueous phase $\mathrm{pH}$ is such that the net charge on the surface of the protein is electrically opposite to that of surfactant [6]. The isoelectric point (pI) of XR produced by Candida tropicalis IEC5-ITV is unknown, although a pI between 4.10 and 4.15 has been reported for Candida tropicalis [16]. Therefore, the XR described in the present study, at the $\mathrm{pH}$ used in the forward extraction $(\mathrm{pH} 7)$, can have a negative global charge, and the surfactant, $\mathrm{CTAB}$, under these conditions, a positive charge which favors XR inclusion in the reverse micelles. In the backward extraction, the $\mathrm{pH}$ value must allow the protein to have the same charge as the surfactant molecules; in our case, the $\mathrm{pH}$ of the backward extraction was 5.5 which favored the positive charge of XR. When the surfactant has the same charge, protein repulsion forces are created and the micellar diameter is decreased, causing the release of the protein [9]. Electrostatic interactions, which may cause enzyme migration to the micellar core, are one of the most prevalent factors in reverse micelles extraction and explain the high recovery of XR in this study (Table 1). XR recovery was over $100 \%$ since all the activity of the enzyme present in the crude extract was transferred to the fresh aqueous phase after backward extraction, no activity of XR was detected in API. A range of transfer efficiencies have been found including $100 \%$ efficiency or complete transfer into reverse micelles [2].

Using reversed micelles of BDBAC [ $N$-benzyl- $N$-dodecyl- $N$-bis (2-hydroxyethyl) ammonium chloride] cationic surfactant, Cortez et al. [10] recovered about 136\%
XR from C. guilliermondii FTI 20037 and the same researchers using CTAB [9-11] and the same organism recovered $100 \%$ XR. A purification factor of 8.1 fold obtained in this study compares favorably to those mentioned above (4.1 and 5.6, respectively). This difference can be attributed to variations between protocols. The main differences were fermentation medium (a hydrolyzate of sugarcane bagasse concentrate containing 42 $\mathrm{g} \cdot \mathrm{L}^{-1}$ xylose and controlled aeration conditions versus a synthetic medium with $30 \mathrm{~g} \cdot \mathrm{L}^{-1}$ xylose and uncontrolled air flow) and adjustment of electrical conductivity of the micellar microemulsion (carried out or not). The interacttion of the surfactant with any broth constituents may affect the preferential separation of the desired product [7] and many publications have demonstrated that different ionic strength affects the ability of reverse micelles to entrap the protein [1].

\subsection{Effect of pH on Enzyme Activity and Stability}

A $\mathrm{pH}$ value about of 6.0 was the optimum $\mathrm{pH}$ for $\mathrm{XR}$ activity before extraction (Figure 1).

This result is in agreement with those reported in the literature for other XRs, insofar as the optimum $\mathrm{pH}$ for activity was 6.0 for P. tannophylus [18], P. stipitis [19] and Candida tropicalis [16-20] and 5.5 and 6.0 for Candida guilliermondii FTI 20037 [17].

Table 1. Purification of XR produced by $C$. tropicalis IEC5ITV using reverse micelles.

\begin{tabular}{|c|c|c|c|c|c|}
\hline $\begin{array}{l}\text { Purification } \\
\text { step }\end{array}$ & $\begin{array}{c}\text { Total } \\
\text { protein } \\
(\mathrm{mg} / \mathrm{mL})\end{array}$ & $\begin{array}{l}\text { Total } \\
\text { activity } \\
(\mathrm{U} / \mathrm{mL})(\mathrm{L}\end{array}$ & $\begin{array}{l}\text { Specific } \\
\text { activity } \\
\text { U/mg protein) }\end{array}$ & $\begin{array}{c}\text { Yield } \\
(\%)\end{array}$ & $\begin{array}{l}\text { Purification } \\
\text { factor }\end{array}$ \\
\hline $\begin{array}{c}\text { Crude } \\
\text { extract (CE) }\end{array}$ & 0.316 & 0.242 & 0.77 & 100 & 1.0 \\
\hline $\begin{array}{c}\text { Reverse } \\
\text { micelles (APII) }\end{array}$ & 0.056 & 0.349 & 6.24 & 100 & 8.1 \\
\hline
\end{tabular}

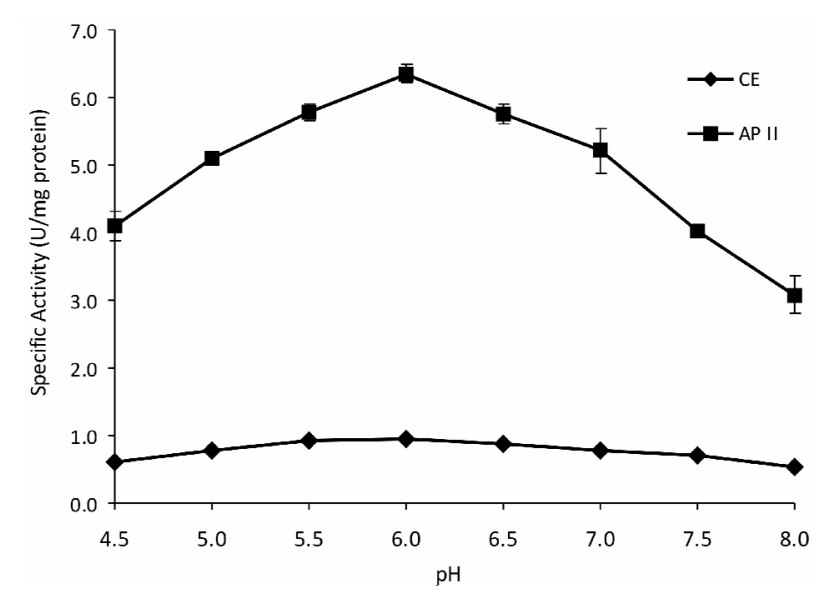

Figure 1. Effect of pH on xylose reductase activity present in crude extract (CE) and purified by reverse micelles (AP II). 
The XR of Candida tropicalis IEC5-ITV in AP II also exhibited a peak of maximum activity at $\mathrm{pH}$ 6.0; Cortez et al. [11] found that the $\mathrm{pH}$ optimum for XR activity for Candida guilliermondii FTI 20037 before and after extraction with reversed micelles was about 6.0 , however maximum XR activity diminished about $44 \%$ after submission to the extraction compared to that found in crude extract, attributing this to the effect of the solvents used in this method, which may affect the conformation of the protein. This was not the case in this study.

The residual specific activity (Table 2) of the XR of Candida tropicalis IEC5-ITV after one hour of incubation at different $\mathrm{pH}$ values, reached an optimum of 7 before and after extraction with reverse micelles, the decrease in activity being attributed to damage in enzyme structure.

\subsection{Effect of Temperature on Enzyme Activity and Stability}

On the other hand, the specific activity of XR from Candida tropicalis IEC5-ITV in the crude extract has an optimum at $40^{\circ} \mathrm{C}$, while the enzyme purified by reverse micelles reaches a temperature of $30^{\circ} \mathrm{C}$, decreasing by $38.5 \%$ at $40^{\circ} \mathrm{C}$ (data not shown). The effect of temperature on the stability of XR of Candida tropicalis IEC5ITV was similar in CE and AP II, since in both fractions enzyme activity is maintained above $90 \%$ between $30^{\circ} \mathrm{C}$ $40^{\circ} \mathrm{C}$, however after incubation for one hour at $50^{\circ} \mathrm{C}$ lost residual specific activity retains $16.6 \%$ and $17.85 \%$ respectively (Table 3). This decline in enzyme activity due to temperature is attributed to enzyme denaturation and/or, in the case of crude extract, to activation of those proteases present. Similar results were found for XR of $C$. guilliermondii FTI 20037 obtained by reverse micelles [11].

\subsection{Determination of $K_{M}$ and $V_{M a x}$}

The values obtained for the kinetic parameters Michaelis-Menten constant $\left(\mathrm{K}_{\mathrm{M}}\right)$ and maximum velocity reaction $\left(\mathrm{V}_{\mathrm{Max}}\right)$ for $\mathrm{XR}$ of $C$. tropicalis IEC5-ITV, showed the following characteristics: the $\mathrm{K}_{\mathrm{M}}$ for xylose increased $77.3 \%$ after extraction $(0.0059 \mathrm{M}$ to $0.026 \mathrm{M})$, while the $\mathrm{K}_{\mathrm{M}}$ for NADPH was $92.9 \%$ lower (12.04 mM to 1.85 $\mathrm{mM})$. The same applies to the $\mathrm{V}_{\mathrm{Max}}$ for xylose $(0.42 \mathrm{U} / \mathrm{L}$ in $\mathrm{CE}$ and $4.53 \mathrm{U} / \mathrm{L}$ in AP II). The same was found by Cortez et al. [11] for XR of C. guilliermondii purified by reverse micelles, only to a lesser extent. In this work the kinetic constants were significantly affected. This can be explained, at least in part, because the enzyme molecules are disrupted in structure during the extraction process, so that as the affinity for the substrate decreases, that for the coenzyme increases [11]. Activity of XR for NADH was not detectable, as reported for XR of $C$. tropicalis
IFO 0618 [16].

\subsection{Enzyme Stability during Storage}

After two months'storage at $-18^{\circ} \mathrm{C}$, enzyme activity before purification remained intact and the purified enzyme lost $76.60 \%$ activity (Figure 2), probably due to its instability given by the contact with solvents during extraction.

\subsection{Molecular Weight Determination of Xylose Reductase}

Enzyme analysis by SDS-PAGE (Figure 3) showed a band present in AP II which coincided in mobility with one present in CE, both with a molecular weight of 32.42

Table 2. Effect of $\mathrm{pH}$ on stability of the XR of Candida tropicalis IEC5-ITV.

\begin{tabular}{ccc}
\hline \multirow{2}{*}{$\mathrm{pH}$} & \multicolumn{2}{c}{ Stability* (\%) } \\
\cline { 2 - 3 } & $\mathrm{CE}$ & $\mathrm{AP} \mathrm{II}$ \\
\hline 4.5 & 39.7 & 73.7 \\
7.0 & 100 & 100 \\
8.5 & 70.2 & 52.0 \\
\hline
\end{tabular}

*Residual activity.

Table 3. Effect of temperature on stability of XR of Candida tropicalis IEC5-ITV.

\begin{tabular}{ccc}
\hline \multirow{2}{*}{ Temperature ${ }^{\circ} \mathrm{C}$} & \multicolumn{2}{c}{ Stability* (\%) } \\
\cline { 2 - 3 } & $\mathrm{CE}$ & AP II \\
\hline 30 & 98.3 & 100 \\
40 & 100 & 86.2 \\
50 & 22.4 & 24.9 \\
60 & 16.4 & 17.8 \\
\hline
\end{tabular}

*Residual activity.

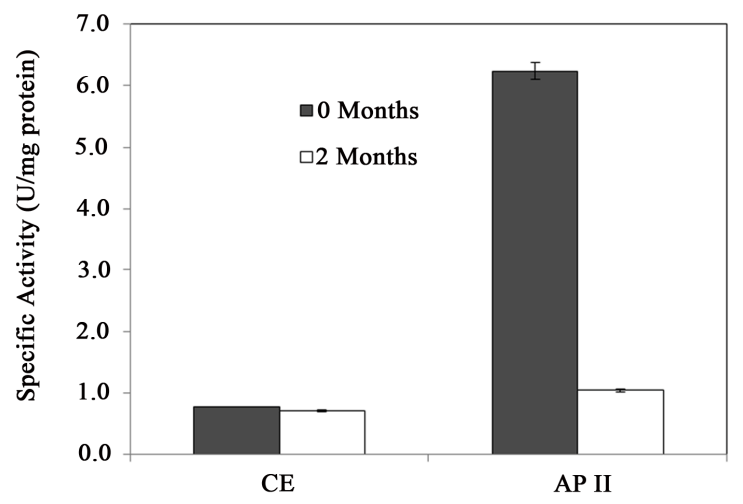

Figure 2. Residual activity of xylose reductase present in the crude extract (CE) and the aqueous phase II (AP II) of Candida tropicalis IEC5-ITV after two months of storage. 


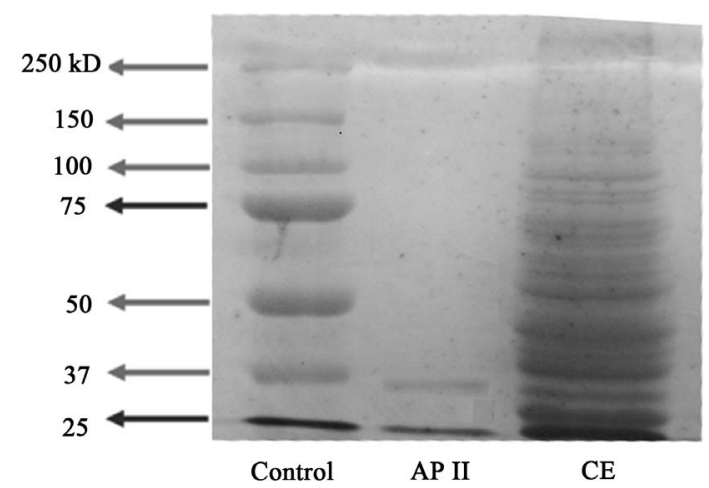

Figure 3. SDS-PAGE of $C$. tropicalis. Lane 1: marker proteins. Lane 2: micellar extract (AP II). Lane 3: crude extract (CE).

$\mathrm{kD}$ which is within the molecular weight range reported for other XRs [20-22]. XRs have been found to be present also as a dimer with subunits approximately $36 \mathrm{kD}$ in molecular weight [20-23] so it is necessary in our case to perform electrophoresis under native conditions to determine whether the XR of Candida tropicalis IEC5ITV is composed of one or more subunits. The presence of two additional bands, with molecular weights of 54.95 and $66.06 \mathrm{kD}$, was also noted but to a lesser extent, indicating that XR is not the only protein extracted under these conditions. This suggests that these two proteins have the size and appropriate charge to be included in the reverse micelle. Hence, a further step of purification is required to obtain a homogeneous product.

\section{Conclusions}

The use of reversed micelles for the extraction and purification of xylose reductase from Candida tropicalis IEC5-ITV resulted in a considerable saving of time and reagents. The recovery yield obtained in this work was $100 \%$ and the enrichment factor was 8.1. A partial preliminary characterization of the enzyme was achieved, showing that the kinetic parameters are modified when the enzyme is purified, the $K_{M}$ increasing for xylose and decreasing for NADPH. A further step of purification and structure sequencing will allow us to better understand their stability and kinetic changes observed in this study.

\section{Acknowledgements}

This work is part of the project entitled "Technology for sustainable development in the production of xylitol and energy from sugarcane bagasse", No. 31346. Fondo Mixto CONACYT-Gobierno del Estado de Veracruz. (National Council of Science and Technology-Veracruz State Government Mixed Fund). Authors acknowledge the critical reading of Patricia Hayward Jones MSc. and Dulce María Barradas Dermitz MSc.

\section{REFERENCES}

[1] B. V. Kilikian, M. R. Bastazin, N. M. Minami, E. M. R. Goncalves and A. Pessoa Jr., "Liquid-Liquid Extraction by Micelles in Biotechnological Processes," Brazilian Journal of Chemical Engineering, Vol. 17, No. 1, 2000, pp. 1-14. doi:10.1590/S0104-66322000000100003

[2] A. Carlson and R. Nagarajan, "Release and Recovery of Porcine Pepsin and Bovine Chymosin from Reverse Micelles: A New Technique Based on Isopropyl Alcohol Addition," Biotechnology Progress, Vol. 8, No. 1, 1992, pp. 85-90. doi:10.1021/bp00013a013

[3] T. X. Zhang, H. Z. Liu and J. Y. Chen, "Extraction of Yeast Alcohol Dehydrogenase Using Reversed Micelles Formed with CTAB," Journal of Chemical Technology and Biotechnology, Vol. 75, 2000, pp. 798-802. doi:10.1002/1097-4660(200009)75:9<798::AID-JCTB28 2>3.0.CO;2-P

[4] E. M. G. Rodrigues and E. B. Tambourgi, "Continuous Extraction of Xylanase from Penicillium janthinellum with Reversed Micelles Using Experimental Design Mathematical Model," Biotechnology Letters, Vol. 23, No. 5, 2001, pp. 365-367. doi:10.1023/A:1005659618433

[5] F. A. Hasmann, C. D. Vieira, A. Pessoa Jr. and I. C. Roberto, "Optimization of $\beta$-Xylosidase Recovery by Reversed Micelles Using Response Surface Methodology," Electronic Journal of Biotechnology, Vol. 6, No. 2, 2003, pp. 153-160.

[6] L. F. P. Ferreira, M. E. Taqueda, A. Converti, M. Vitolo and A. Pessoa Jr., "Purification of Glucose Oxidase from Aspergillus niger by Liquid-Liquid Cationic Reversed Micelles Extraction," Biotecnology Progress, Vol. 21, No. 3, 2005, pp. 868-874. doi:10.1021/bp049623x

[7] J. G. Liu, J. M. Xing, T. S. Chang and H. Z. Liu, "Purification of Nattokinase by Reverse Micelles Extraction from Fermentation Broth: Effect of Temperature and Phase Volume Ratio," Bioprocess Biosystems Engineering, Vol. 28, No. 4, 2006, pp. 267-273. doi:10.1007/s00449-005-0032-1

[8] E. V. Cortez, A. Jr. Pessoa, M. G. Almeida-Felipe, I. C. Roberto and M. Vitolo, "Liquid-Liquid Extraction of Xylitol Dehydrogenase from Candida guilliermondii Homogenate by Reversed Micelles," Journal Chromatography $B$, Vol. 807, No. 1, 2004, pp. 55-60. doi:10.1016/j.jchromb.2004.03.034

[9] E. V. Cortez, A. Pessoa, M. G. Almeida-Felipe Jr., I. C. Roberto and M. Vitolo, "Optimized Extraction by Cetyl Trimethyl Ammonium Bromide Reversed Micelles of Xylose Reductase and Xilitol Dehydrogenase from Candida guilliermondii Homogenate," Journal Chromatography B, Vol. 807, No. 1, 2004, pp. 47-54. doi:10.1016/j.jchromb.2004.02.011

[10] E. V. Cortez, M. G. Almeida-Felipe, I. C. Roberto, A. Pessoa Jr. and M. Vitolo, "Extraction by Reversed Micelles of the Intracelular Enzyme Xilose Reductase," Applied Biochemical Biotechnology, Vol. 91-93, 2001, pp. 753- 759. doi:10.1385/ABAB:91-93:1-9:753

[11] E. V. Cortez, A. Pessoa Jr., M. G. Almeida-Felipe, I. C. Roberto and M. Vitolo, "Characterization of Xylose Re- 
ductase Extracted by CTAB-Reversed Micelles from Candida guilliermondii Homogenate," Brazilian Journal of Pharmaceutical Sciences, Vol. 42, No. 2, 2006, pp. 251-257.

[12] T. B. Granström, K. Izumori and M. Leisola, "A Rare Sugar Xylitol. Part I: The Biochemistry and Biosynthesis of Xylitol," Applied Microbiology and Biotechnology, Vol. 74, No. 2, 2007, pp. 277-278. doi:10.1007/s00253-006-0761-3

[13] R. S. Prakasham, R. S. Rao and P. J. Hobbs, "Current trends in Biotechnological Production of Xylitol and Future Prospects," Current Trends Biotechnology Pharmacy, Vol. 3, No. 1, 2009, pp. 8-36.

[14] E. Gastélum, "Producción de Xilitol por la Levadura IEC5-ITV a Partir de Hidrolizado de Bagazo de Caña en Cultivo por Lote Alimentado," Master Dissertation, Veracruz Institute of Technology, Veracruz, 2007.

[15] D. M. Bollag, M. D. Rozycki and S. J. Edelstein, "Protein Methods," 2th Edition, John Wiley \& Sons, New York, 1996.

[16] S. I. Yokoyama, T. Suzuki, K. Kawai, H. Horitsu and K. Takamizawa, "Purification, Characterization and Structure Analysis of NADPH-Dependent D-Xylose Reductases from Candida tropicalis," Journal of Fermentation and Bioengineering, Vol. 79, No. 3, 1995, pp. 217-223. doi:10.1016/0922-338X(95)90606-Z

[17] L. Sene, M. G. A. Felipe, S. S. Silva and M. Vitolo, "Preliminary Kinetic Characterization of Xylose Reductase and Xylitol Dehydrogenase Extracted from Candida guilliermondii FTI 20037 Cultivated in Sugarcane Bagasse Hydrolysate for Xylitol Production," Applied Biochemestry and Biotechnology, Vol. 91-93, No. 1-9, 2001, pp. 671-680.
[18] G. Dietzelmüller, C. P. Kubicek, W. Wöhrer and M. Röehr, "Xylose Metabolism in Pachysolen tannophilus: Purification and Propierties of Xylose Reductase," Canadian Journal of Microbiology, Vol. 30, No. 11, 1984, pp. 13301336. doi: $10.1139 / \mathrm{m} 84-214$

[19] C. Verduyn, R. Van-Kleef, J. Frank, H. Schreuder, J. P. Van-Dijken and A. W. Scheffers, "Properties of the NAD (P)H-Dependent Xylose Reductase from the Xylosefermenting Yeast Pichia stipitis," Biochemical Journal, Vol. 226, No. 3, 1985, pp. 669-677.

[20] A. A. Abou Zeid, M. Z. El-Fouly, Y. A. El-Zawahry, T. M. El-Mongy and A. B. Abd El-Aziz, "Bioconversion of Rice Straw Xylose to Xylitol by a Local Strain of Candida tropicalis," Journal of Applied Sciences Reserche, Vol. 4, No. 8, 2008, pp. 975-986.

[21] X. Zhao, P. Gao and Z. Wang, "The Production and Properties of a New Xylose Reductase from Fungus Neurospora crassa," Applied Biochemestry and Biotechnology, Vol. 70, No. 72, 1998, pp. 405-414. doi:10.1007/BF02920155

[22] U. B. Rawat and M. B. Rao, "Purification, Kinetic Characterization and Involvement of Trypstophan Reside at the NADPH Binding Site of Xylose Reductase from Neurospora crassa," Biochemica et Biophysica Acta, Vol. 1293, No. 2, 1996, pp. 222-230. doi:10.1016/0167-4838(95)00249-9

[23] P. K. Mayr, K. D. Kulbe and B. Nidetzky, "D-Xylose Metabolism by Candida intermedia: Isolation and Characterisation of Two Forms of Aldose Reductase with Different Coenzyme Specificities," Journal of Chromatography B, Vol. 737, 2002, pp. 195-202. doi:10.1016/S0378-4347(99)00380-1 